\title{
Dějiny vzdělanosti na sjezdu historiků v Olomouci (13.-15. 9. 2017)
}

Olomouc letos hostila po tři dny velké zástupy českých historiků, kteří přijeli, aby zde ve zdech historických budov i v moderním konferenčním centru předvedli svým kolegům výsledky vlastní práce a podělili se informacemi o aktuálních trendech historického bádání. Již jedenáctý sjezd se skládal vedle zahajovací přednášky hostující americké profesorky Lynn Hunt a závěrečného plenárního zasedání z tří hlavních sekcí a osmi desítek volných panelů. ${ }^{1} \mathrm{~V}$ rámci nich přišla na program také tematika dějin vzdělanosti, a to nejen ve smyslu dějin nižšího školství a univerzit, ale i vzdělanosti v širokém výměru toho pojmu. Zaměříme se právě na tuto oblast, která je předmětem zájmu našeho časopisu.

Na prvním místě je třeba poreferovat o samostatném panelu věnovaném dějinám vzdělanosti a vzdělávání v ČR. Organizátoři a garanti panelu - doc. Martin Holý (Historický ústav AV ČR) a dr. Petr Kadlec (Centrum pro hospodářské a sociální dějiny Ostravské univerzity) - vymezili jeho program jako bilanci stavu a formulování perspektiv výzkumu v této oblasti. V tomto ohledu př́mo navazovali na předchozí bilanci představenou na Sjezdu historiků v Hradci Králové v r. 1999. ${ }^{2}$ Dodejme zároveň, že výsledná podoba olomouckého panelu vznikla spojením dvou původně navrhovaných a podobně zaměřených panelů, na jejichž př́pravě se podíleli také doc. Miroslav Novotný (Filozofická fakulta Jihočeské univerzity) a dr. Marek Ďurčanský (Ústav dějin a archiv UK). Jednání proběhlo ve třech blocích, v rámci nichž zaznělo 12 referátů.

První blok byl zaměřen převážně na prameny $k$ dějinám vzdělanosti a jejich zpř́ístupňování. B. Zilynská a M. Ďurčanský se pokusili představit hlavní ediční počiny související s tradičními středoevropskými univerzitami (Praha, Krakov, Vídeň) předmoderní doby, včetně výhledů do nejbližších let a s vazbami na proběhnuvší i plánovaná jubilea. Př́íspěvek I. Hlaváčka byl shrnutím současného stavu výzkumu středověkých knihoven v českých zemích a svého druhu také vyznáním obdivu ke knize jakožto historickému fenoménu. Naopak možnosti moderních „digital humanities“ na př́kladu rekonstrukce raně novověkých učeneckých korespondenčních sítí byly předmětem zájmu V. Urbánka; konkrétně byly představeny oxfordské projekty Cultures of Knowledge a Early Modern Letters Online, resp. evropský projekt Reassembling the Republic of Letters. N. Morávková uzavřela blok př́ispěvkem zaměřeným na odborné biografie osobností $\mathrm{z}$ oblasti dějin vzdělanosti a prameny $\mathrm{k}$ nim, zejména možnosti využití oral history. $\mathrm{V}$ diskusi k celému bloku rezonoval především potenciál (ale také nemalá úskalí) moderních způsobů zpř́istupňování a digitálních médií vůbec.

I následující blok vzhledem $\mathrm{k}$ nepřítomnosti jednoho $\mathrm{z}$ avizovaných přednášejících sestával ze čtyř referátů. M. Holý se v př́spěvku připraveném společně $\mathrm{s} M$. Holou zamýšlel nad současnými trendy a perspektivami v oblasti výzkumu dějin středověké a raně novověké vzdělanosti - i tady samožrejmě došlo na výzvy digitálního věku. Chronologicky i tematicky na něj plynule navázal druhý z garantů panelu P. Kadlec, který se zabýval obdobím od 18. století po současnost. Výstižně přitom rozlišil př́ístupy tradičních dějin školství od možností komplexnějšího pojetí, jež dnes již mezi publikovanými texty nejsou výjimkou.

1 Abstrakty jsou k dispozici na webu: http://historieolomouc2017.upol.cz/hlavni-zasedani/; http://historieolomouc2017.upol.cz/kongresove-volne-panely/ <ověřeno 5. 9. 2018>.

2 Práce z Archivu Akademie věd, roč. 7, 2002 (vyšlo 2003). 
Škálu různých konkrétních přístupů v praxi následně představil na př́ikladu francouzské historiografie a „nových dějin školstvi““ J. Hnilica. Přehledový charakter měl př́spěvek M. Bahenské zaměřený na vzdělání a vzdělávání žen ve středoevropském prostoru - téma, které je zjevně na vzestupu.

Poslední blok přinesl čtyři metodologicky orientovaná vystoupení, založená ovšem na konkrétních badatelských zkušenostech a projektech. Tak byla v př́spěvku M. Novotného na příkladu jižních Čech tematizována problematika regionálního školství, zejména v souvislosti s vazbou na konkrétní lokální urbánní centrum (České Budějovice). Komplexně pojatý výzkum inteligence v dlouhém časovém úseku druhé poloviny 19. a první poloviny 20. století byl představen A. Pokludovou na př́kladu Ostravska. Dějinami medicíny jakožto tradiční, ale zároveň trvale atraktivní oblasti dějin vzdělanosti se zabýval P. Svobodný. Závěrečný př́ispěvek T. W. Pavlíčka byl zaměřen na problematiku kolektivního vědomí a generačních diskurzů ve vědě (a to zejména na př́íkladu české astronomie). Následující diskuse byla velmi živá a vracela se $\mathrm{k}$ řadě konkrétních metodických problémů a metodologických podnětů jednotlivých př́íspěvků.

Větší část př́spěvků z panelu k dějinám vzdělanosti by měla vyjít jako monotematické číslo AUC-HUCP. Snad bude z výsledku zřejmé to, co se přinejmenším části účastníků během jednání jevilo jako rozhodně prrínosné - propojení badatelů od nejstarších období po současnost umožňující alespoň v hrubých obrysech vnímat dějiny vzdělanosti v českých zemích jako celek.

Zásadní příspěvky $\mathrm{k}$ dějinám vzdělanosti v 19. a 20. století se objevily též v dalších sekcích, byly tedy nahlíženy z jiných úhlů pohledu nebo v rámci jiných diskurzů. Sekce Vytvárenei sociálních sití, jejich význam a role při utvárenei moderních společností věnovala velkou pozornost také tzv. vzdělaneckým profesím, jednomu z významných segmentů širšího vymezení dějin vzdělanosti (vzdělaneckým profesím/inteligenci se věnoval také výše zmíněný metodologický referát $\mathrm{A}$. Pokludové). $\mathrm{V}$ programu této sekce byly avizovány referáty mj. o moravských advokátech na přelomu 19. a 20. století, učitelích základních škol a středoškolské struktuře v rakouském Slezsku na přelomu 19. a 20. století. Specifické postavení $\mathrm{v}$ rámci sekce měl referát J. Mareše o trvalém působení sociálních sítí vytvářených studenty německých vysokých škol v českých zemích v rámci tzv. buršenšaftů.

Velmi blízkou dějinám vzdělanosti byla sekce Vědecké poznáni a př́běh pokroku jako mýtus moderni doby garantovaná doc. M. Francem (MÚA AV ČR) a prof. J. Hanušem (HÚ MU Brno). Tezi o vědeckém pokroku jako „mýtu moderní doby“ nejlépe odpovídaly brilantní referáty J. Hanuše Kritikové mýtu a pokroku a L. Fasory Pod tlakem prírodních věd-poznámky k jednomu mýtu humanitních věd 20. století. Dva na sebe tematicky navazující př́ípadové referáty se zabývaly počátečními obdobími ČSAV (A. Jůnová Macková, M. Franc). Úvodní teoretičtější referáty se dvěma př́ípadovými propojoval dobře vypointovaný referát $\mathrm{T}$. Hermanna o „roli politických náboženstvi““ (na příkladu tzv. mičurinské biologie v ČSR).

$\mathrm{O}$ aplikaci metod orální historie $\mathrm{v}$ oblasti soudobých dějin vzdělanosti, respektive dějin vědy, jsme se mohli poučit u kolegů orálních historiků v jejich sekci. J. Hlaváček zde představil několik konkrétních (vy)řešených projektů $\mathrm{v}$ referátu Intelektuálni elity jako předmět orálně-historického výzkumu. Metodologická úskalí a jejich možná rěšení (nejbližší autorovi této části zprávy byla informace o výzkumu vědecké komunity soudních lékařù). 
$\mathrm{K}$ dějinám vzdělanosti se vztahovaly i další bloky či jednotlivé referáty. $\mathrm{V}$ rámci panelu Osobni a kolektivní biografie v prostředi digital humanities pracovníci ÚDAUK P. Cajtha$\mathrm{ml}$ a L. Vašková přednesli př́spěvek Databáze univerzitních studentik jako nástroj prosopografického a biografického výzkumu. Referující v úvodu shrnuli možnosti zpřístupnění a digitalizace pramenů týkajících se univerzitních studentů v moderní době včetně jejich možného databázového zpracování. Představili nejvýznamnější domácí a zahraniční projekty a přiblížili dlouhodobě probíhající projekt digitalizace studentik pražských univerzit z let 1882 až 1945, ${ }^{3}$ který realizuje Archiv Univerzity Karlovy. V následné diskusi byla probírána šíře možného využití takto zpř́istupněných pramenů a limity databázového zpracování rozsáhlých souborů digitalizovaných archiválií s osobními údaji.

Ve stejném panelu vystoupil se svým př́spěvkem Biografické a evidenční prameny dokumentující působení kapucinských řeholniků v českých zemích (1600-1800) a možnosti jejich využití také další pracovník ÚDAUK M. Brčák. Popsal prameny, jež se dají využít k sestavení životopisů kapucínů žijících v českých zemích v období raného novověku, a prezentoval i konkrétní výsledky získané z jejich výzkumu, např. geografický a sociální původ kapucínů, průměrný věk, ve kterém vstupovali do rádu a jehož se dožívali, systém vzdělávání v rámci řádové formace, jazyková vybavenost bratř́i či četnost migrace mezi řeholními domy atd. Tyto závěry, kde to bylo možné, komparoval se situací v jiných řeholních ř́dech.

V programu dalších panelů se objevila tematika vzdělanosti a vzdělanců starší doby. $\mathrm{K}$ univerzitě měly vztah všechny př́spěvky věnované středověkým univerzitním mistrům a jejich literární tvorbě, soustředěné především v panelech Století změn (P. Cermanová, K. Voleková, P. Soukup) a Koncily 15. století (D. Coufal, O. Matys, A. Pálka). Mistři zde vystupovali jako exegeti Bible, kazatelé, nebo také diplomaté (především v souvislostech zápasu konciliarismu a papežství). M. Dekarli (panel The History of Bohemian Reformation - Interdisciplinary Approaches) přednesl úvahu na téma tzv. předchůdců Husových a L. Mazalová se ve stejné sekci věnovala kázáním v kapli Betlémské.

Na specifika výuky středověkých notářù v rámci vyšehradské notářské školy se na sjezdu zaměřil D. Havel v rámci sekce Vera ac falsa discernere. Nové promýšlení starých disciplín.

Specifickou formou vzdělávání je cestování, spojené s krátkodobějšími zastávkami ve vzdělávacích zařízeních navštívených zemí. Této problematice se účastníci sjezdu věnovali v rámci sekce Dějiny cestování či dějiny turismu? Z Z př́spěvků je třeba vyzdvihnout zejména vystoupení $M$. Lenderové, zaměřené na cesty českých cestovatelek (napříc sociálními vrstvami) do Itálie v 18.-20. století, a referát I. Korbelářové, věnující se privátnímu cestování urozených žen $\mathrm{v}$ předmoderní době. $\mathrm{V}$ obou zazněly četné zmínky o návštěvách vedle památek též výchovných a vzdělávacích institucí. Také problematika počátků organizované turistiky a souvisejícího spolkového života $\mathrm{v} 19$. a na počátku 20 . století, která byla v rámci sekce př́tomna v př́spěvcích Marcely Týfové, Martina Pelce a Martina Vostřela, má k dějinám vzdělanosti blízko - řada protagonistů počátků turistiky se rekrutovala z prostředí studentstva a lokálních intelektuálních elit.

Otázky dějin vědy a vzdělanosti nezůstaly stranou ani v rámci sekce Rusko a Evropa, dependence a protiklady. Možnost paralelních pohledů?. Ve svém př́ispěvku Rusko a střední Evropa v 18. století se jich dotkl F. Stellner, který upozornil na vzájemnou provázanost

3 Výsledky projektu jsou př́stupné na adrese: http://is.cuni.cz/webapps/archiv/public <ověřeno 6. 2. 2018>. 
středoevropského a ruského vědeckého prostředí, nebot' počátky ruské akademie věd i moskevské univerzity jsou neodmyslitelně spjaty s vědci pocházejícími zejména ze středoevropských německy mluvících oblastí.

V rámci sekce Kulturni fenomény ve středoevropských dějinách: obraz, komunikace, jednání byl přednesen J. Lachem a T. Borovským v souvislosti s dějinami vzdělanosti velice zajímavý př́spěvek Podoby komunikace a jednání v české historické obci prvni poloviny 20. století, který se týkal mj. výuky historických oborů na československých univerzitách. Ty byly jedněmi z center, kde se utvářela česká historická věda $v$ tomto období.

Na závěr tohoto shrnutí můžeme formulovat představu o hlavních trendech současného výzkumu dějin vzdělanosti. Pro středověk dominuje v aktuálním badatelském snažení výzkum literárního díla jednotlivých vzdělanců. Počínaje raným novověkem je cítit razantní nástup moderních médií - digitalizace, databázové postupy apod., pro moderní dobu pak oral-history př́stup. Dalším trendem je ústup od tradičních dějin školství k modernějším postupům přihližžjícím $\mathrm{k}$ společenskému sítování a komplexnějšímu pojetí výzkumu inteligence různých dob a segmentů společnosti (např. vzdělaneckých profesí). Zdůrazněna byla i proměna generačních diskurzů ve vědě, mezi něž můžeme zahrnout napřs. mýtus pokroku ve vědě. Bilance obsáhla jak badatelské výsledky, tak rovinu jejich komunikace směrem $\mathrm{k}$ veřejnosti, zvláště v rámci školní výuky a vysokoškolského studia. Sjezdová jednání tak splnila svůj účel informovat, vytvořit kontakty a formulovat vize dalšího postupu.

M. Brčák - P. Cajthaml-M. ら̌určanskýM. Sekyrková - P. Svobodný - L. Vašková - B. Zilynská doi: $10.14712 / 23365730.2018 .59$ 